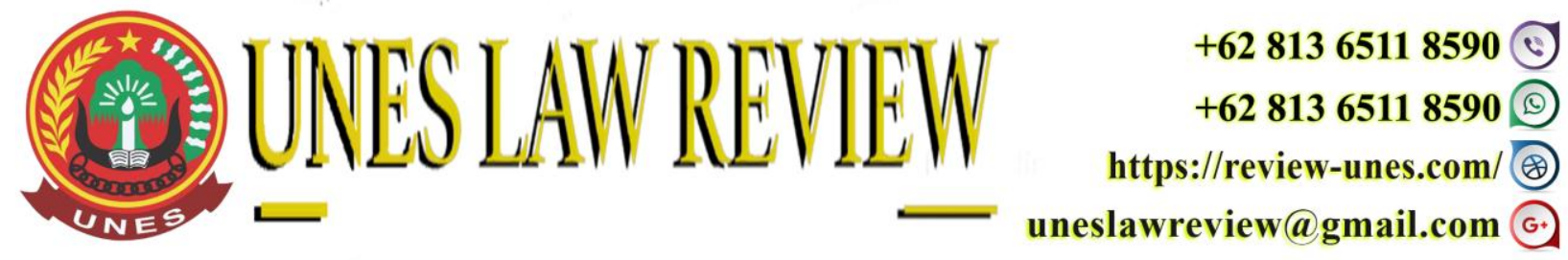

DOI: https://doi.org/10.31933/unesrev.v4i2

Diterima: 20/12/2021, Diperbaiki: 10/01/2022, Diterbitkan: 15/01/2022

\title{
PENYIDIKAN TINDAK PIDANA PERBANKAN DALAM BENTUK KREDIT FIKTIF PADA BANK PERKREDITAN RAKYAT (BPR) MITRA DANAGUNG (Studi Pada Satreskrim Polres Pesisir Selatan)
}

\section{Ichsan Ansari}

Program Magister Ilmu Hukum, Fakultas Hukum, Universitas Ekasakti, Padang, Indonesia.

Email: ichsan_ansari@gmail.com

Corresponding Author: Ichsan Ansari

\section{ABSTRACT}

Article 49 of Law no. 10 of 1998 concerning Banking has explicitly regulated criminal acts related to bank business. However, there are still many parties who commit criminal acts in the banking sector, one of which is fictitious credit. Like the fictitious credit that happened to the Rural Bank (BPR) Mitra Danagung, which was carried out by the Director of Bank Mitra Danagung himself, in the period from 2011 to 2012. The formulation of the problems studied in this thesis are: First, how is the investigation of banking crimes in the form of fictitious loans at BPR Mitra Danagung Bank? Second, what are the obstacles faced by the Satreskrim Investigator of the Pesisir Selatan Police in the investigation of banking crimes in the form of fictitious credit at Bank BPR MitraDanagung? This research is a legal research with a descriptive analytical specification. The main approach used is a normative juridical approach and is supported by an empirical juridical approach. The data used are secondary data as primary data, and primary data as supporting data collected through library research and field research. The data is then analyzed qualitatively and presented in a qualitative descriptive form. Based on the results of the study, it can be concluded, first, that the investigation of banking crimes in the form of fictitious credit at PBR Mitra Danagung Bank was carried out based on the principle of lex specialis derogat legi generalis. After receiving the report, the investigative team conducts an investigation and review of the report to prepare a plan for investigative activities, followed by examining witnesses and collecting evidence and expert testimony, then a case is held to determine the suspect, then arrests and detentions are made. After the filing is complete, the investigator submits the case file to the Public Prosecutor accompanied by witnesses and evidence. Second, the obstacles faced by the investigators of the Satreskrim Polres Pesisir Selatan in the investigation of banking crimes in the form of fictitious credit at Bank BPR Mitra Danagung are: the overlapping authority of investigating banking crimes as regulated by a law that gives authority to the Police, Prosecutors, and Investigators. OJK, limited human resources for investigators, level of education and low knowledge of investigators about advances in 
information technology, as well as supporting facilities and infrastructure in conducting investigations.

Keywords: Investigation, Fictitious Credit

\begin{abstract}
ABSTRAK
Pasal 49 UU No. 10 Tahun 1998 tentang Perbankan telah mengatur secara tegas tindak pidana yang berkaitan dengan usaha bank. Namun masih banyak pihak yang melakukan tindak pidana di bidang perbankan, salah satunya adalah kredit fiktif. Seperti halnya kredit fiktif yang terjadi pada Bank Perkreditan Rakyat (BPR) Mitra Danagung yang dilakukan oleh Direktur Bank Mitra Danagung sendiri, dalam kurun waktu 2011 sampai dengan tahun 2012. Rumusan masalah yang dikaji dalam skripsi ini adalah: Pertama, bagaimana penyidikan tindak pidana perbankan berupa pinjaman fiktif pada Bank BPR Mitra Danagung? Kedua, apa kendala yang dihadapi Penyidik Satreskrim Polres Pesisir Selatan dalam penyidikan tindak pidana perbankan berupa kredit fiktif di Bank BPR Mitra Danagung? Penelitian ini merupakan penelitian hukum dengan spesifikasi deskriptif analitis. Pendekatan utama yang digunakan adalah pendekatan yuridis normatif dan didukung oleh pendekatan yuridis empiris. Data yang digunakan adalah data sekunder sebagai data primer, dan data primer sebagai data pendukung yang dikumpulkan melalui penelitian kepustakaan dan penelitian lapangan. Data tersebut kemudian dianalisis secara kualitatif dan disajikan dalam bentuk deskriptif kualitatif. Berdasarkan hasil penelitian dapat disimpulkan, pertama, bahwa penyidikan tindak pidana perbankan berupa kredit fiktif pada Bank PBR Mitra Danagung dilakukan berdasarkan asas lex specialis derogat legi generalis. Setelah menerima laporan, tim penyidik melakukan penyelidikan dan penelaahan atas laporan tersebut untuk menyusun rencana kegiatan penyidikan, dilanjutkan dengan pemeriksaan saksi-saksi dan pengumpulan barang bukti dan keterangan ahli, kemudian diadakan perkara untuk menetapkan tersangka, kemudian dilakukan penangkapan dan penahanan. dibuat. Setelah pengajuan selesai, penyidik menyerahkan berkas perkara kepada Penuntut Umum disertai dengan saksi dan alat bukti. Kedua, kendala yang dihadapi penyidik Satreskrim Polres Pesisir Selatan dalam penyidikan tindak pidana perbankan berupa kredit fiktif di Bank BPR Mitra Danagung adalah: tumpang tindih kewenangan penyidikan tindak pidana perbankan sebagaimana diatur dalam undang-undang yang memberikan kewenangan kepada penyidik. Polisi, Kejaksaan, dan Penyidik. OJK, keterbatasan SDM penyidik, tingkat pendidikan dan rendahnya pengetahuan penyidik tentang kemajuan teknologi informasi, serta sarana dan prasarana penunjang dalam melakukan penyidikan.
\end{abstract}

Kata Kunci: Investigasi, Kredit Fiktif

\title{
PENDAHULUAN
}

Pengaturan mengengai fungsi dan tugas serta tanggung jawab oleh bank dalam perkembangan dewasa ini dirasakan sangat penting, mengingat bank merupakan salah satu lembaga keuangan yang sangat dipercaya oleh masyarakat, tidak hanya itu, bank juga merupakan sarana dalam hal pengiriman di berbagai belahan negara di dunia, sehingga peran dan manfaat bank sangat dirasakan bagi kelancaran ekonomi, khususnya bagi pelaku usaha dan secara umum bagi masyarakat.

Hal ini sejalan dengan apa yang disebutkan Teguh Pugdjo Mulyono, ia mengatakan bahwa perbankan sebagai lembaga keuangan mempunyai peran yang strategis dalam kegiatan perekonomian melalui kegiatan usahanya menghimpun dana masyarakat dan menyalurkan 
pembiayaan bagi usaha-usaha produktif maupun konsumtif, sekaligus menjadi penentu arah bagi perumusan kebijakan pemerintah di bidang moneter dan keuangan dalam mendukung stabilitas pembangunan nasional, khususnya untuk dapat menjadi tempat penyimpanan dana yang aman, tempat yang diharapkan dapat melakukan kegiatan pembiayaan demi kelancaran dunia usaha dan perdagangan. ${ }^{1}$

Kehadiran bank sebagai penyedia jasa keuangan tidak terlepas dari kebutuhan masyarakat untuk mengajukan pinjaman atau pembiayaan kepada bank. Pembiayaan merupakan suatu istilah yang sering disamakan dengan hutang atau pinjaman yang pengembaliannya dilaksanakan secara mengangsur. Hal ini menunjukkan bahwa upaya seseorang untuk memenuhi kebutuhan dana atau finansial dapat ditempuh dengan melakukan pinjaman atau pembiayaan kepada bank. Setiap aktivitas perbankan harus memenuhi asas ketaatan perbankan, yaitu segala kegiatan perbankan yang diatur secara yuridis dalam Undang-Undang Nomor 10 Tahun 1998 tentang Perbankan, serta termasuk menjalankan prinsip-prinsip perbankan (prudent banking) dengan cara menggunakan rambu-rambu hukum berupa safe dan sound. Kegiatan bank secara yuridis dan secara umum adalah penarikan dana masyarakat, penyaluran dana kepada masyarakat, kegiatan fee based, dan kegiatan dalam bentuk investasi. ${ }^{2}$

Perubahan yang dilakukan terhadap Undang-Undang No. 7 Tahun 1992 menjadi UndangUndang Nomor 10 Tahun 1998 telah menambah usaha yang dapat dilakukan oleh bank. Untuk bank umu, jenis usaha yang ditambah adalah menyediakan pembiayaan dan atau melakukan kegiatan lain berdasarkan prinsip syari'ah, sesuai dengan ketentuan yang ditetapkan oleh Bank Indonesia. Sementara pada Bank Perkreditan Rakyat, jenis usaha yang ditambah adalah menyediakan pembiayaan dan penempatan dana berdasarkan prinsip syariah, sesuai dengan ketentuan yang ditetapkan oleh Bank Indonesia.

Namun dalam perkembangannya, penambahan kegiatan usaha melalui perubahan UU Perbankan ternyata meningkatkan kesempatan timbulnya kemungkinan seseorang atau kelompok orang untuk melakukan perbuatan melawan hukum terhadap dunia perbankan (tindak pidana perbankan). Semakin luas kesempatan yang muncul, juga akan berbanding lurus dengan semakin banyaknya jenis dan ruang lingkup tindak pidana perbankan berdasarkan peruaturan umum di dalam KUHP dan yang diatur secara khusus di dalam UU Perbankan dan peraturan perundangundangan di luar KUHP selain UU Perbankan.

Tindak pidana perbankan merupakan salah satu bentuk kejahatan ekonomi dan kejahatan jabatan. Virus ini sangat mudah menyerang birokrasi perbankan terutama di negara-negara berkembang seperti Indonesia. penyebabnya tidak lain sangatlah multidimensional, tapi yang sangat dominan adalah watak non-demokratis serta tata sistem manajemennya. Semua itu bisa dari sebuah negara, demi meningkatkan pembangunan ekonomi, negara cenderung bersikap totaliterastik dan konservatif.

Tindak pidana perbankan pada dasarnya merupakan perbuatan melawan hukum yang dilakukan baik dengan sengaja ataupu dengan tidak sengaja yang ada hubungannya dengan

\footnotetext{
${ }^{1}$ Teguh Pudjo Mulyono, Manajemen Perkreditan Bagi Bank Komersil, BPFE, Yogyakarta, 2006, hlm. 56

${ }^{2}$ Ibid, hlm. 57
} 
lembaga, perangkat dan produk perbankan, sehingga menimbulkan kerugian materiil dan atau immateriil bagi perbankan itu sendiri maupun bagi nasabah atau pihak ketiga lainnya. ${ }^{3}$

Salah satu tindak pidana yang seringkali muncul dari usaha usaha perbankan, baik bank umum maupun bank perkreditan rakyat adalah tindak pidana yang berkaitan dengan usaha kredit. Dan tindak pidana yang seringkali muncul akibat pemberlakuan kebijakan pemberian kredit adalah kredit fiktif.

Modus kejahatan di bidang perbankan, khususnya kredit fiktif, dilakukan dengan cara menggunakan dokumen atau jaminan palsu, fiktif, penyalahgunaan pemakaian kredit, mendapat kredit berulang-ulang dengan jaminan objek yang sama, memerintahkan, menghilangkan, menghapuskan, tidak membukukan yang seharusnya dipenuhi. Di samping itu modus operandinya juga memaksa bank atau pihak yang terafiliasi memberikan keterangan yang wajib dirahasiakan, tidak memberikan keterangan yang wajib dipenuhinya kepada Bank Indonesia maupun kepada Penyidik Negara, menerima, meminta, mengijinkan, menyetujui untuk menerima imbalan, uang tambahan, pelayanan komisi, uang atau barang berharga untuk kepentingan pribadi dalam rangka orang lain mendapat kredit, uang muka, prioritas kredit atau persetujuan orang lain untuk melanggar batas maksimum pemberian kredit (BMPK). ${ }^{4}$

Kasus kejahatan perbankan (kredit fiktif) bisa melibatkan orang yang bekerja di bank (orang dalam), dimana tindak kejahatan tersebut dilakukan sendiri, sesama orang dalam, maupun melibatkan pihak luar.Ini artinya dalam melakukan kejahatan kredit fiktif, terdapat oknumoknum bank yang menyalahgunakan wewenang yang diberikan.

Kredit fiktif pada perkembangan dewasa ini dinilai sangat merugikan keuangan negara, sehingga jikapun digolongkan sebagai extra ordinari crime terasa sudah sangat wajar. Beberapa kasus kredit fiktif yang merugikan kerugian negara hingga triliunan rupiah adalah kasus kredit fiktif Bank Mandiri, kasus kredit fiktif bank BTN dan Bank BRI.

Kasus kredit fiktif pada Bank Mandiri Bandung yang melaibatkan tiga pejabat Bank Mandiri, yakni Surya Beruna (commercial banking manager Bank Mandiri Bandung), Teguh Kartika Wibowo (senior credit risk manager Bank Mandiri Bandung), dan Frans Eduard Zandstra (senior credit risk manager Bank Mandiri Bandung), serta satu terdakwa lainnya direktur PT TAB Roni Tedi, telah mengakibatkan kerugian negara hingga mencapai Rp. 1,83 triliun. ${ }^{5}$ Dalam persidangan, Jaksa menyebutkan Roni terbukti telah memalsukan laporan keuangan dengan seolah-olah memiliki aset dan piutang mencapai Rp. 1,1 triliun. Sehingga dirinya mengjukan kredit kepada Bank Mandiri. Namun kenyataannya, laporan keuangan tersebut tidak ada alias fiktif. Jaksa juga menyebutkan bahwa Roni mengajukan fasilitas kredit sejahk 2008 hingga 2012 dengan data-data fiktif. ${ }^{6}$

Pada Bank BTN Cabang Cikarang, kasus kredit fiktif mengakibatkan kerugian negara hingga Rp 4,2 miliar. Kasus kredit fiktif pada Bank BTN Cikarang dilakukan oleh Neli Apriani,

\footnotetext{
${ }^{3}$ Marfein Halim, Mengurai Benang Kusut, Bank Indonesia, Jakarta, 2002, hlm. 28

${ }^{4}$ Ibid

${ }^{5}$ Selengkapnya https://news.detik.com/berita-jawa-barat/d-4188680/kredit-fiktif-rp-183-t-pejabat-bank-didakwa-20tahun-bui diunduh pada tanggal 15 Januari 2019

${ }^{6}$ Ibid
} 
karyawan debitu Bank BTN Cabang Cikarang. Ia juga dituntut melakukan tindak pidana korupsi dalam pencairan kredit fiktif dengan memperkaya orang lain, yaitu PT. Mitra Cahaya Sentosa (PT CMS). ${ }^{7}$ Sedangkan pada Bank BRI, kasus kredit fiktif dilakukan oleh komplotan yang memakai KTP Suami Istri palsu. Komplotan ini telah berhasil membobol 11 unit BRI di Kota Semarang dalam rentang waktu November 2016 sampai dengan Februari 2017. ${ }^{8}$

Kredit Fiktif tidak hanya terjadi di kota-kota besar, bank-bank umum, tetapi juga telah merambah ke berbagai daerah di Indonesia dan juga terjadi pada bank perkreditan rakyat. Salah satunya adalah kasus kredit fiktif yang terjadi Pada Bank Perkreditan Rakyat (BPR) Mitra Danagung Kabupaten Pesisir Selatan.

Kredit Fiktif pada BPR Mitra Danagung yang menjerat Risman Edrival selaku eks Direktur Bank Mitra Danagung terjadi dalam selang waktu tahun 2011 hingga tahun 2012. Cara yang dilakukan adalah dengan menggunakan data-data nasabah yang pernah mengajukan pinjaman pada Bank Nagari Mitra Danagung dan belum pernah disetujui kreditnya namun kredit nasabah tersebut dicairkan tanpa sepengatahuan nasabah, Nasabah yang tidak pernah melakukan pinjaman yang namanya digunakan hingga kredit dicairkan, dan Nasabah pernah mendapat fasilitas pinjaman dari pihak Bank BPR Mitra Danagung namun sudah atau belum lunas dengan jumlah pinajaman yang sama sekali berbeda dengan yang dicatatkan tetapi kredit dicairkan.

Kerugian yang diakibatkan oleh tindak pidana kredit fiktif pada Bank BPR Mitra Danagung mencapai Rp. 772.000.000,,- (Tujuh Ratus Tujuh Puluh Dua Juta Rupiah) dengan nama nasabah yang dipakai sebanyak 23 (dua puluh tiga orang). ${ }^{9}$

Perkara/kasus kredit fiktif yang terjadi pada Bank Nagari Mitra Danagung telah disidangkan di Pengadilan Negeri Painan dan telah memperoleh kekuatan hukum tetap melalui Putusan Nomor 71/Pid.Sus/2018/PN Pnn. Dalam dakwaannya, Jaksa Penuntut Umum menuntut Terdakwa dengan Pasal 49 ayat (1) huruf a Undang-Undang No. 10 Tahun 1999 tentang Perbankan jo Pasal 55 ayat (1) ke-1 KUHP atau Pasal 49 ayat (2) huruf b Undang-Undang No. 10 Tahun 1999 tentang Perbankan jo Pasal 55 ayat (1) ke-1 KUHP, karena telah melakukan, menyuruh melakukan atau turut serta melakukan perbuatan, membuat atau menyebabkan adanya pencatatan palsu dalam pembukuan atau dalam proses laporan, maupun dalam dokumen atau laporan kegiatan usaha, laporan transaksi atau rekening suatu bank.

Berdasarkan fakta yang terungkap selama persidangan, Hakim Pengadilan Negeri Painan melalui Putusan No. 71/Pid.Sus/2018/PN Pnn, memilih dakwaan alternative Kedua sebagaimana diatur di dalam Pasal 49 ayat (2) huruf b Undang-Undang No. 10 Tahun 1999 tentang Perbankan jo Pasal 55 ayat (1) ke-1 KUHP. Berdasarkan fakta persidangan, pertimbangan, dan keyakinan hakim, terdakwa secara meyakinkan melakukan perbuatan yang memenuhi unsur-unsur: 1) Anggota Dewan Komisaris, Direksi, atau pegawai Bank, 2) dengan sengaja, 3) Tidak melaksanakan langkah-langkah yang diperlukan untuk memastikan ketaatan bank terhadap

\footnotetext{
7 Selengkapnya https://www.viva.co.id/berita/nasional/1110407-karyawan-korupsi-kredit-fiktif-rp4-2-miliardihukum-bui-lima-tahun, diunduh Pada tanggal 15 Januari 2019

${ }^{8}$ Selengkapnya http://www.tribunnews.com/regional/2017/05/19/komplotan-kredit-fiktif-ini-berhasil-bobo-11-unitbri-pakai-suami-istri-palsu?page=1, diunduh pada tanggal 15 Januari 2019

${ }^{9}$ Putusan Nomor 71/Pid.Sus/2018/PN Pnn
} 
ketentuan dalam Undang-Undang ini dan ketentuan-ketentuan dalam Undang-Undang ini dan ketentuan peraturan perundang-undangan lainnya yang berlaku bagi Bank, dan 4) Orang yang melakukan, menyuruh melakukan atau turut melakukan. Kemudian Hakim menjatuhkan hukuman kepada Terdakwa dengan hukuman pidana penjara selama 3 (tiga) tahun dan pidana desa sebesar Rp. 5.000.000.000,- (lima Milyar Rupiah) dengan ketentuan apabila denda tidak dibayar diganti dengan pidana kurungan selama 2 (dua) bulan.

Penelitian ini menitikberatkan pada proses penyidikannya. Hal ini dikarenakan dalam sistem peradilan pidana, penyidikan merupakan langkah awal yang untuk mengidentifikasi apakah benar suatu perbuatan tersebut adalah tindak pidana atau bukan sehingga proses selanjutnya dari pada penegakan hukum dapat dilanjutkan.

Hal yang sama juga berlaku bagi tindak pidana perbankan. Penegakan hukum akan dimulai dari proses penyidikan. Pada tahap ini, dimungkinkan bagi penyidik untuk meneruskan atau tidak meneruskan pemeriksaan tindak pidana perbankan dalam proses peradilan pidana. ${ }^{10}$

Penulis memandang tindak pidana perbankan khususnya tindak pidana kredit fiktif merupakan jenis tindak pidana yang tersembunyi, tersistematis, dan teroganisis sehingga sulit untuk dilacak pada saat proses penyidikan. Terlebih lagi jika bukti-bukti terkait tindak pidana telah hilang.

\section{METODE PENELITIAN}

Sepesifikasi penelitian adalah deskriptif analitis, dengan menggunakan metode Pendekatan Yuridis Normatif dan Yuridis Empiris. Jenis data yang digunakan adalah data sekunder yang diperoleh melalui penelitian kepustakaan dan data primer melalui penelitian lapangan. Data yang diperoleh dianalisis secara kualitatif dan disajikan dalam bentuk deskriptif.

\section{HASIL DAN PEMBAHASAN}

\section{Penyidikan Tindak Pidana Perbankan dalam Bentuk Kredit Fiktif pada Bank BPR Mitra Danagung}

Kepolisian Negara Republik Indonesia merupakan pintu masuk utama dalam proses penyelesaian suatu perkara pidana. Sebagai salah satu sub sistem dalam sistem peradilan pidana, yang terletak di depan (sebagai gerbang utaama), keberadaan kepolisian menjadi sangat urgen dalam rangka mencari dan menemukan apakah suatu tindak pidana telah terjadi berdasarkan laporan/pengaduan masyarakat beserta bukti-bukti yang ditemukan.

Barda Nawawi Arief mengemukakan bahwa Sistem Peradilan Pidana hakikatnya identik dengan sistem penegakan hukum pidana dan juga diidentikkan dengan sistem kekuasaan kehakiman dibidang hukum pidana yang diwujudkan dalam empat sub sistem, yaitu:

1. Kekuasaan penyidikan oleh lembaga penyidik.

2. Kekuasaan penuntutan oleh lembaga penuntut.

3. Kekuasaan mengadili/menjatuhkan putusan oleh badan peradilan, dan.

4. Kekuasaan pelaksanaan hukum pidana oleh aparat pelaksana eksekusi. ${ }^{11}$

\footnotetext{
${ }^{10}$ I Ketut Sudira, Mediasi Penar Perkara Penelantaran Rumah Tangga, UII Press, Yogyakarta, 2016, hlm. 111
} 
Keempat tahap/sub sistem itu merupakan satu kesatuan sistem penegak hukum pidana yang integral, dan sering disebut dengan istilah SistemPeradilan Pidana Terpadu (Integrated criminal justice system $)^{12}$.

Pemahaman terhadap sistem peradilan pidana terpadu atau SPPT yang sesungguhnya, bukan saja pemahaman dalam konsep "integrasi" itu sendiri, tetapi sistem peradilan pidana yang terpadu juga mencakup makna substansial dari urgensitas simbolis prosedur yang terintegrasi tetapi juga menyentuh aspek filosofis mengenai makna keadilan dan kemanfaatan secara terintegrasi. Sehingga dengan demikian penegakan hukum pidana materiil yang dikawal dan dibingkai oleh norma peraturan perundangan yang menjadi wilayah hukum pidana prosedural, dapat lebih didekatkan pada prinsip dan substansi penegakan hukum yang sekaligus menegakkan keadilan dan penegakan hukum yang bermartabat. ${ }^{13}$

Sementara itu Muladi mengemukakan bahwa sistem peradilan pidana sesuai dengan makna dan ruang lingkup sistem dapat bersifat phisik dalamarti sinkronisasi struktural (structural syncronization) dalam arti keselarasan mekanisme administrasi peradilan pidana, dapat pula bersifat substansial(substancial syncronization) dalam kaitannya dengan hukum positif yangberlaku, dan dapat pula bersifat kultural (cultural syncronization) dalam artimenghayati pandangan, sikap, dan falsafah yang secara menyeluruhmendasari jalannya sistem peradilan pidana. ${ }^{14}$

Upaya terbaik menegakkan hukum pidana meteril selalu menuntut dan bersandar pada bagaimana ketentuan hukum pidana formil untuk mampumengawal tujuan hukum pidana materil itu sendiri. Kejahatan menjadi sasaran tuduhan akibat lemahnya penegakan hukum materil, jika saja perangkat hukum yang mengatur komponen dalam sistem peradilan juga lemah.

Dalam sistem peradilan pidana, lembaga penyidik yaitu lembaga yang melaksanakan kekuasaan penyidikan, adapun pejabat yang diberi wewenang sebagai penyidik oleh undangundang adalah antara lain:

1. Pejabat Polri (Pasal 6 KUHAP)

2. PPNS (Pasal 6 KUHAP) dan UU Khusus diluar KUHP

3. Perwira TNI AL, berkaitan UU ZEEI, UU Konservasi Hayati, UU Pelayaran.

Penyidikan dalam alur penanganan perkara pidana merupakan alur kedua setelah penyelidikan yang dilakukan oleh kepolisian manakala telah dipastikan suatu perbuatan merupakan tindak pidana melalui proses penyelidikan.

Proses penyidikan secara yuridis memberikan kewenangan kepada penyidik untuk untuk menggunakan upaya paksa seperti menangkap dan menetapkan seseorang sebagai tersangka, karenanya dalam hal diperlukan profesionalisme seorang penyidik untuk menjamin hak-hak asasi

\footnotetext{
${ }^{11}$ Barda Nawawi Arief, Kapita Selekta Hukum Pidana Tentang System Peradilan Pidana Terpadu, BP Undip, Semarang, 2007, hlm. 11

${ }^{12}$ Barda Nawawi Arief, Reformasi Sistem Peradilan (Sistem Penegakan Hukum di Indonesia), Cet. II BP Undip, Semarang, 2011, hlm. 7

${ }^{13}$ Edi Setiadi, Kristian, Sistem Peradilan Pidana Terpadu dan Sistem Penegakan Hukum di Indonesia, Edisi Pertama, Prenadamedia Group, Jakarta, 2017, hlm. 31

${ }^{14}$ Muladi, Kapita Selekta Sistem Peradilan Pidana, Undip, Semarang, 1995, hlm. 13
} 
tersangka, perintah penangkapan tersebut harulah didasarkan pada adanya bukti permulaan yang cukup.

Berdasarkan Pasal 17 KUHAP, bukti permulaan yang cukup ialah bukti permulaan untuk menduga adanya tindak pidana. Pasal ini menentukan bahwa perintah penangkapan tidak dapat dilakukan sewenang-wenang kepada mereka yang betul-betul melakukan tindak pidana.

Bukti permulaan yang cukup merupakan persyaratan untuk dapat melakukan tindakan: ${ }^{15}$

1. Penyidikan

2. Menetapkan status tersangka

Keputusan Rapat Kerja Gabungan Mahkamah Agung, Menteri Kehakiman, Jaksa Agung, dan Kepolisian Republik Indonesia (RAKERGAB MAKEHJAPOL) tanggal 21 Maret 1984 memutuskan bahwa bukti permulaan yang cukup segogyanya adalah Laporan Polisi ditambah satu alat bukti lainnya. ${ }^{16}$

KUHAP mensyaratkan bahwa dari bukti-bukti tersebut dapat diduga adanya tindak pidana (untuk melakukan penyidikan) atau dari bukti-bukti tersebut harus dapat diduga bahwa seseorang adalah pelaku tindak pidana (untuk menetapkan tersangka). Bukti permulaan yang cukup hanya dikenal dan hanya digunakan dalam proses penyelidikan, maka bukti permulaan yang cukup dapat terdiri atas: ${ }^{17}$

1. Keterangan.

2. Keterangan saksi.

3. Keterangan ahli, dan

4. Barang bukti

Peranan barang bukti dalam pemeriksaan perkara pidana utamanya pada tingkat penyidikan sangat dibutuhkan sebagai bukti awal dalam pemeriksaan perkara pidana. Barang bukti kadang-kadang sangat dibutuhkan dalam rangka memperjelas tindak pidana yang terjadi, begitu pula untuk memudahkan mengklarifikasi tindak pidana tersebut dan memudahkan untuk menemukan pelakunya. Keberadaan barang bukti dan keterangan saksi menjadi lebih urgen manakala suatu tindak pidana yang akan diselidiki adalah tindak pidana yang dilakukan secara sistematis, seperti kredit fiktif dalam tindak pidana perbankan.

Kredit fiktif memiliki kaitan yang erat dengan pencatatan palsu, dan pemberian imbalan dari nasabah bank yang memperoleh fasilitas dari bank. Kredit Fiktif merupakan suatu tindakan kecurangan (fraud) pada bidang kredit yang dilakukan oleh pihak intern (pegawai) bank dengan cara melakukan kolusi dengan nasabah pemohon kredit, keduanya sama-sama tidak memiliki itikad baik karena tujuan dari dilakukannya kredit fiktif adalah untuk menguntungkan diri sendiri. Dalam kredit kredit fiktif juga ditemukan mengenai pemalsuan jaminan kredit. Akibatnya nasabah yang identitasnya dipakai tanpa izin dalam kredit fiktif sangat dirugikan baik dalam segi materiil maupun imateriil, seperti yang dilakukan oleh pegawai PT. Bank BPR Mitra Danagung terhadap terhadap 23 data nasabah.

\footnotetext{
${ }^{15}$ Candra M. Hamzah, Penejelasan Hukum Tentang Bukti Permulaan Yang Cukup, Pusat Studi Hukum dan Kebijakan Indonesia (PSHK), Jakarta, 2014, hlm. 6

${ }^{16}$ Ibid, hlm. 8-9

${ }^{17}$ Ibid, hlm. 17-18
} 
Tindak pidana kredit fiktif merupakan tindak pidana perbankan yang diatur secara khusus di dalam Undang-Undang No. 7 Tahun 1992 tentang Perbankan sebagaimana telah diubah dengan Undang-Undang No. 10 Tahun 1998 tentang Perubahan Atas Undang-Undang No. 7 Tahun 1992 tentang Perbankan. Karenanya dalam penyidikannya tidak menggunakan Kitab Undang-Undang Hukum Pidana (KUHP) melainkan menggunakan Undang-Undang Perbankan. Dalam asas hukum ini dikenal dengan sebutan (lex specialis derogate legi generali) yang berarti ketentuan hukum yang khusus mengenyampingkan ketentuan hukum yang umum (ketentuan Undang-Undang Perbankan mengenyampingkan KUHP).

Menurut Sudikno Mertokusumo asas hukum umum ialah asas hukum yang berhubungan dengan seluruh bidang hukum, seperti asas restitution in integrum, berarti bahwa asas yang lahirnya tampak benar, untuk sementara harus dianggap demikian sampai diputus (lain) oleh penggadilan. Sementara itu asas hukum khusus berfungsi dalam bidang yang lebih sempit seperti dalam bidang hukum perdata, hukum pidana dan sebagainya, yang sering merupakan penjabaran dari asas hukum umum, seperti asas pacta sun servanda, asas konsesualisme, maupun asas praduga tak bersalah. ${ }^{18}$

Prosedur penyidikan tindak pidana kredit fiktif yang terjadi pada PT. Bank BPR Mitra Danagung dimulai dengan adanya Laporan Polisi oleh Adeh Rahcmat dengan Nomor: LP.516/V/2016/Bareskrim, tertanggal 7 Mei 2016. Berdasarkan keterangan pelapor, ia mengetahui adanya dugaan tindak pidana perbankan di PT. BPR Mitra Danagung dari informasi Tim Likuidasi BPR Mitra Danagung (DL) yang menemuka adanya indikasi kredit fiktif terhadap debitur yang dilakukan oleh pengurus bank.

Setelah adanya laporan, selanjutnya penyidik bersama tim penyidik melakukan penelitian terhadap laporan tersebut untuk menentukan: Klasifikasi perbuatan yang dilaporkan/akan ditangani, Menyusun rencana kegiatan penyidikan, Membuat rencana kebutuhan anggaran penyidikan, dan Menetapkan target waktu penyelesaian penanganan perkara tersebut.

Berdasarkan hasil penelitian tim penyidik terhadap laporan yang diterima, kemudian diterbitkanlah surat Surat Perintah Penyidikan No: S.Sidik / 56 / IX / 2016 / Reskrim, tertanggal 21 September 2016. Surat Perintah Penyidikan tersebut menugaskan AKP Elisabet Dewi Rustika dan Iptu Nofrizal Can sebagai Penyidik, kemudian dibantu oleh Aipda Ichsan Ansari, Bripka Riki Kurniawan, Bripka Herianto Sitanggang, Bripka Romi Rusli, Brigadir Agung Wahyu Saptono, Brigadir Vitryano Fajrah Roza sebagai Penyidik Pembantu.

Setelah terbitnya Surat Perintah Penyidikan No: S.Sidik / 56 / IX / 2016 / Reskrim, tertanggal 21 September 2016, kemudian diiringi dengan penerbitan Surat Pemberitahuan Dimulainya Penyidikan (SPDP) No: SPDP 07 / II / 2018 / Reskrim tertanggal 26 Februari 2018. Berdasarkan surat perintah penyidikan inilah penyidik Polres Pesisir Selatan dapat melaksanakan tugasnya untuk melakukan penyidikan terhadap dugaan terjadinya tindak pidana kredit fiktif pada Bank BPR Mitra Danagung.

Terdapat 31 (tiga puluh satu) orang saksi termasuk pelapor dan tersangka dan 3 (tiga) orang ahli yang diperiksa dalam penyidikan tindak Pidana Perbankan dalam Bentuk Kredit Fiktif

\footnotetext{
${ }^{18}$ Sudikno Mertokusumo, Mengenal Hukum (Suatu Pengantar), Edisi Ketiga, Liberty, Yogyakarta, 1991, hlm. 36
} 
pada Bank BPR Mitra Danagung. Adapun saksi-saksi tersebut adalah: Ade Rachmat (Pelapor), Asmarial, Suhardi, Rika Nurmalia, Didi Prakoso, Risman Edrival (Tersangka), Ramadhani, Almauri Fatul Putri, Mira Laura, Parida, Zaidil Masri, Marzaili, Idel Maliharni Binti Zet April, Firda Dezi Marza, Syamsurijal, Busli, Dedeng Putra, Siska Rahmi, Nasrizal, Guneli, Sarniati, Yusmar Linda, Idel Miliharni, Yulia Erni, Si El, Etmawati, Sarifatul Jannah, Selvi Desmi Novita (Tersangka), Hamidah (Tersangka), Joniza Efendi (Tersangka), Murin Nurus (Tersangka), Bustamudin (Ahli), Eni Yarni (Ahli), Nuril Muchendrawan (Ahli)

Berdasarkan keterangan awal yang diberikan oleh saksi kemudian penyidik bergerak untu mencari dan mengumpulkan alat bukti yang berupa surat-surat serta bukti petunjuk lainnya yang dapat memperjelas bahwa perbuatan yang dilaporkan tersebut adalah benar suatu tindak pidana.

Berdasarkan keterangan dari Saksi-saksi dari PT. BPR Mitra Danagung, Tim Liquidasi, dan LPS, serta tim Investigasi LPS, dugaan tindak Pidana Perbankan berupa peberian pinajamn kredit yang diduga fiktif atau direkayasa tersebut terjadi semenjak bulan Januari 2011 sampai dengan Desember 2012, yang mana terdapat dugaan penyimpangan praktik perbankan yang tidak sesuai dengan ketentuan PT. BPR Mitra Danagung yang merujuk pada temuan pemeriksaan investigasi yang telah dilakukan berdasarkan atas informasi awal yang disampaikan Group Likuidasi kepada Group Investigasi dari Lembaga Penjamin Simpanan (LPS). Adapun rincian perjanjian kredit fiktif pada PT. BPR Mitra Danagung adalah sebagai berikut:

\section{Tabel 1}

Rincian Perjanjian Kredit Fiktif pada PT. BPR Mitra Danagung

\begin{tabular}{|c|c|c|}
\hline No. & Debitur & Kelengkapan Dokumen Kredit \\
\hline 1. & $\begin{array}{l}\text { Murniati } \\
\text { No. PK } 608 \text { / PT. BPR-MD / IN / } \\
122012 \text { / } 122012\end{array}$ & $\begin{array}{l}\text { Tidak ada AJB Asli } \\
\text { Tidak ada pengikatan jaminan }\end{array}$ \\
\hline 2. & $\begin{array}{l}\text { Syamsurijal } \\
\text { No. PK: 0636/PT. BPR- } \\
\text { MD/IN/082011/082014 }\end{array}$ & $\begin{array}{l}\text { Tidak ada sertifikat asli } \\
\text { Tidak ada pengikatan jaminan } \\
\text { Tidak ada KTP } \\
\text { Tidak ada PK } \\
\text { Tidak ada validasi penerimaan uang }\end{array}$ \\
\hline 3. & $\begin{array}{l}\text { Busli } \\
\text { No. PK: 378/PT. BPR- } \\
\text { MD/IN/062012/062017 }\end{array}$ & $\begin{array}{l}\text { Tidak ada pengikatan jaminan } \\
\text { Tidak ada PK }\end{array}$ \\
\hline 4. & $\begin{array}{l}\text { Lizar } \\
\text { No. PK: } 454 \text { / PT. BPR-MD / IN / } \\
\text { 082012/082015 }\end{array}$ & $\begin{array}{l}\text { Tidak ada pengikatan jaminan } \\
\text { Tidak ada PK } \\
\text { Tidak ada validasi penerimaan uang } \\
\text { Tidak ada tanda tangan penerima jaminan }\end{array}$ \\
\hline 5. & $\begin{array}{l}\text { Zulandri } \\
\text { No. PK: 522/PT. BPR- } \\
\text { MD/IN/102012/102013 }\end{array}$ & $\begin{array}{l}\text { Tidak ada pengikatan } \\
\text { Tidak ada PK } \\
\text { Persetujuan Komite Kredit tidak ditandatangani } \\
\text { direktur }\end{array}$ \\
\hline 6. & $\begin{array}{l}\text { Dedeng Putra } \\
\text { No. PK: 0899 / PT. BPR-MD / IN / } \\
01212 / 012015\end{array}$ & $\begin{array}{l}\text { Tidak ada pengikatan jaminan } \\
\text { Persetujuan Komite Kredit tidak ditandatangani } \\
\text { direktur }\end{array}$ \\
\hline 7. & $\begin{array}{l}\text { Siska Rahmi } \\
\text { No. PK: 578/PT. BPR- } \\
\text { MD/IN/122012/122015 }\end{array}$ & $\begin{array}{l}\text { Tidak ada pengikatan } \\
\text { Tidak ada sertifikat jaminan asli } \\
\text { Tidak ada tanda tangan penerima jaminan }\end{array}$ \\
\hline 8. & $\begin{array}{l}\text { Gusnelli } \\
\text { No. PK: } 404 \text { / PT. BPR-MD IN / }\end{array}$ & $\begin{array}{l}\text { Tidak ada sertifikat asli } \\
\text { Tidak ada pengikatan jaminan }\end{array}$ \\
\hline
\end{tabular}




\begin{tabular}{|c|c|c|}
\hline & $072012 / 072015$ & $\begin{array}{l}\text { Tidak ada PK } \\
\text { Tidak dilakukan survey lapangan } \\
\text { Tidak ada validasi pada voucher penerimaan }\end{array}$ \\
\hline 9. & $\begin{array}{l}\text { Yelpa Nora } \\
\text { No. PK: } 446 \text { / PT. BPR-MD / IN / } \\
072012 / 072015\end{array}$ & $\begin{array}{l}\text { Tidak ada pengikatan jaminan } \\
\text { Tidak ada PK } \\
\text { Tidak dilakukan survey lapangan } \\
\text { Tidak ada tanda tangan penerima jaminan }\end{array}$ \\
\hline 10. & $\begin{array}{l}\text { Sarniati } \\
\text { No. PK: 456 / PT. BPR-MD / } \\
\text { IN/082012/082015 }\end{array}$ & $\begin{array}{l}\text { Tidak ada sertifikat asli } \\
\text { Tidak ada pengikatan jaminan } \\
\text { Tidak ada PK } \\
\text { Tidak dilakukan survey lapangan } \\
\text { Tidak ada validasi pada voucher penerimaan }\end{array}$ \\
\hline 11. & $\begin{array}{l}\text { Yusmar Linda } \\
\text { No. PK: 001 / PT. BPR-MD / IN / } \\
\text { 012013/012016 }\end{array}$ & $\begin{array}{l}\text { Tidak ada sertifikat asli } \\
\text { Tidak ada pengikatan jaminan } \\
\text { Tidak ada PK } \\
\text { Tidak dilakukan survey lapangan } \\
\text { Tidak ada validasi pada voucher penerimaan } \\
\text { Tidak ada tanda tangan penerima jaminan }\end{array}$ \\
\hline 12 . & $\begin{array}{l}\text { Sustra Rida } \\
\text { No. PK: 003 / PT. BPR-MD / IN / } \\
\text { 012013/012016 }\end{array}$ & $\begin{array}{l}\text { Tidak ada sertifikat asli } \\
\text { Tidak ada pengikatan jaminan } \\
\text { Tidak ada PK } \\
\text { Tidak dilakukan survey lapangan } \\
\text { Tidak ada tanda tangan penerima jaminan }\end{array}$ \\
\hline 13. & $\begin{array}{l}\text { Idel Miliharni } \\
\text { No. PK: } 0201 \text { / PT. BPR-MD / IN / } \\
\text { 042012/042013 }\end{array}$ & $\begin{array}{l}\text { Tidak ada pengikatan jaminan } \\
\text { Tidak dilakukan survey lapangan }\end{array}$ \\
\hline 14. & $\begin{array}{l}\text { Yulia Erni } \\
\text { No. PK: } 362 \text { / PT. BPR-MD / IN / } \\
062012 / 062013\end{array}$ & $\begin{array}{l}\text { Tidak ada pengikatan jaminan } \\
\text { Tidak ada PK } \\
\text { Tidak ada dokumen serah terima jaminan } \\
\text { Tidak dilakukan survey lapangan }\end{array}$ \\
\hline 15 . & $\begin{array}{l}\text { Yon Hendri } \\
\text { No. PK: } 382 \text { / PT. BPR-MD / IN / } \\
062012 / 062013\end{array}$ & $\begin{array}{l}\text { Tidak ada sertifikat asli } \\
\text { Tidak ada pengiaktan jaminan } \\
\text { Tidak ada PK } \\
\text { Tidak dilakukan survey lapangan } \\
\text { Tidak ada validasi pada voucher penerimaan }\end{array}$ \\
\hline 16. & $\begin{array}{l}\text { Ermansyah } \\
\text { No. PK: } 433 \text { / PT. BPR-MD / IN / } \\
072012 / 072015\end{array}$ & $\begin{array}{l}\text { Tidak ada pengikatan jaminan } \\
\text { Tidak dilakukan survey lapangan }\end{array}$ \\
\hline 17. & $\begin{array}{l}\text { Si El } \\
\text { No. PK: } 503 \text { / PT. BPR-MD / IN / } \\
\text { 092012/092016 }\end{array}$ & $\begin{array}{l}\text { Tidak ada pengikatan jaminan } \\
\text { Tidak dilakukan survey lapangan } \\
\text { PK tidak ditandatangani pejabat BPR } \\
\text { Tidak ada petugas survey lapangan } \\
\end{array}$ \\
\hline 18. & $\begin{array}{l}\text { Etmawati } \\
\text { No. PK: } 604 \text { / PT. BPR-MD / IN / } \\
\text { 122912/122013 }\end{array}$ & $\begin{array}{l}\text { Tidak ada Pengikatan jaminan } \\
\text { Tidak dilakukan survey lapangan } \\
\text { Tidak }\end{array}$ \\
\hline 19. & $\begin{array}{l}\text { Seprisma Yanto } \\
\text { No. PK: } 560 \text { / PT. BPR-MD / IN / } \\
\text { 122012/122013 }\end{array}$ & $\begin{array}{l}\text { Tidak ada pengikatan jaminan } \\
\text { Tidak ada sertifikat asli } \\
\text { Tidak ada PK } \\
\text { Tidak ada tanda tangan penerima jaminan } \\
\text { Tidak dilakukan survey lapangan }\end{array}$ \\
\hline 20. & $\begin{array}{l}\text { Muso Laini } \\
\text { No. PK: 002 / PT. BPR-MD / IN / } \\
\text { 012013/012016 }\end{array}$ & $\begin{array}{l}\text { Tidak ada dokumen jaminan } \\
\text { Tidak ada pengikatan jaminan } \\
\text { Tidak ada PK } \\
\text { Tidak ada validasi pada voucher penerimaan } \\
\text { Tidak dilakukan survey lapangan } \\
\end{array}$ \\
\hline
\end{tabular}




\begin{tabular}{|l|l|l|}
\hline 21. & $\begin{array}{l}\text { Eni Yarni } \\
\text { PK: 0825 / PT. BPR-MD / IN / } \\
012013 / 012026\end{array}$ & $\begin{array}{l}\text { Tidak ada penyerahan jaminan } \\
\text { Tidak ada pengikatan jaminan } \\
\text { Tidak dilakukan survey lapangan } \\
\text { Tidak ada voucher penerimaan uang }\end{array}$ \\
\hline 22. & $\begin{array}{l}\text { Sarifatul Jannah } \\
\text { No. PK: 058 / PT. BPR-MD / IN / } \\
\text { 012011/012014 }\end{array}$ & $\begin{array}{l}\text { Tidak ada pengikatan jaminan } \\
\text { Tidak ada sertifikat asli } \\
\text { Tidak dilakukan survey lapangan } \\
\text { Tidak ada voucher penerimaan uang } \\
\text { Tida }\end{array}$ \\
\hline 23. & $\begin{array}{l}\text { Bustamuddin } \\
\text { No. PK: 042 / PT. BPR-MD / IN / } \\
\text { 112012/112015 }\end{array}$ & $\begin{array}{l}\text { Tidak ada pengikatan jaminan } \\
\text { Tidak ada PK } \\
\text { Tidak ada tanda tangan penerima jaminan }\end{array}$ \\
\hline
\end{tabular}

Sumber: Saterskrim Polresta Pesisir Selatan

Berdasarkan data rincian perjanjian kredit pada tabel diatas, jelas sekali terlihat perbuatan tersangka melanggar SOP PT. BPR Mitra Danagung dan ketentuan peraturan perundangundangan berkaitan dengan pemberian kredit, yakni dengan: Tidak ada dokumen jaminan, Tidak ada pengikatan jaminan, Tidak ada PK, Tidak ada validasi pada voucher penerimaan, Tidak dilakukan survey lapangan, Tidak ada penyerahan jaminan

Pencarian dan pengumpulan alat bukti yang dilakukan oleh penyidik terbilang cukup rumit karena tindak pidana yang dilakukan termasuk tindak pidana yang sistematis. Ditambah lagi pengawasan yang dilakukan terhadap bank BPR Mitra Danagung terlihat sangat lemah dan tidak terkonsep sebagaimana SOP yang ada. Lemahnya pengawasan dikarenakan jauhnya jarak antara BPR Mitra Danagung dengan badan pengawas. Disamping itu pengawasan yang dilakukan semata-mata hanya untuk mempertahankan berdirinya bank tersebut dan lengah terhadap pengawasan administrasi perkreditan.

Penyidik mendatangi Bank BPR Mitra Danagung untuk meminta keterangan dan dokumen-dokumen terkait dugaan tindak pidana kredit fiktif namum belum langung berbuah hasil maksimal karena meskipun atas kepentingan penyidikan, Direktur Bank BPR Mitra Danagung masih berusaha menutupi dan menyembunyikan beberapa surat-surat dan dokumendokumen nasabah yang namanya dipakai untuk melakukan tindak pidana kredit fiktif dimaksud dengan berbagai alasan.

Setelah mendatangi Bank BPR Mitra Danagung, penyidik melakukan pemanggilan terhadap nasabah yang namanya diduga digunakan untuk tindak pidana kredit fiktif untuk dimintai keterangan sebagai saksi. Akan tetapi tidak seluruh nasabah yang dipanggil tersebut memenuhi panggilan penyidik.

Menyikapi hasil yang didapat dari upaya mendatangi Bank BPR Mitra Danagung serta sikap pasif masyarakat dalam memenuhi panggilan penyidik maka dalam rangka mengoptimalkan upaya mengumpulkan keterangan serta dokumen-dokumen yang dibutuhkan, penyidik bergerak lebih aktif dengan mendatangi nasabah yang diduga namanya telah dipakai untuk pencairan kredit fiktif tersebut.

Kebanyakan dari nasabah tersebut tidak mengetahui bahwa namanya telah digunakan oleh pihak Bank BPR Mitra Danagung untuk melakukan tindak pidana kredit fiktif. Dalam rangka meningkatkan semangat para nasabah tersebut untuk memberikan keterangan, surat-surat 
maupun dokumen lainnya yang berkaitan dengan tindak pidana kredit fiktif, penyidik memberikan motivasi dengan cara menyampaikan kepada nasabah bahwa terdapat dampak buruk bagi diri nasabah akibat perbuatan pihak Bank BPR Mitra Danagung yakni nama nasabah akan terdaftar sebagai black list pada Otoritas Jasa Keuangan sehingga nasabah tersebut tidak dapat lagi melakukan pinjaman kepada bank manapun. Disamping itu juga disampaikan bahwa pihak kepolisian akan sepenuhnya melindungi nasabah tersebut.

Upaya mendatangi nasabah yang namanya diduga digunakan dalam tindak pidana kredit fiktif membuahkan hasil yang memuaskan. Para nasabah yang didatangi oleh penyidik bersedia untuk memberikan keterangan-keterangan, surat-surat maupun dokumen-dokumen untuk mempermudah penyidik mengungkap dugaan tindak pidana kredit fiktif yang dilakukan oleh pegawai Bank BPR Mitra Danagung. Selanjutnya keterangan-keterangan yang didapat oleh penyidik dibuatkan berita acara. Untuk surat-surat dan dokumen-dokumen maka dilakukan penyitaan.

Setelah penyidik selesai melakukan penyidikan terhadap nasabah yang namanya digunakan dalam dugaan tindak pidana kredit fiktif, dan semua keterangan serta bukti-bukti yang didapatkan menunjukkan bahwa perbuatan tersebut adalah tindak pidana, selanjutnya penyidik kembali mendatangi Bank BPR Mitra Danagung. Dengan berpedoman pada keterangan saksi sebelumnya, penyidikpun berhasil menyita surat-surat permohonan kredit yang dipergunakan pegawai bank untuk mendapatkan kredit fiktif. Adapun bukti-bukti yang didapatkan oleh penyidik selama penyidikan tindak pidana perbankan dalam bentuk kredit fiktif pada Bank BPR Mitra Danagung adalah:

1. Foto copi daftar checklist Ketersediaan Data Indikasi Kredit Fiktif PT. BPR Mitra Danagung (Dalam Likuidasi).

2. Foto Copi Surat Keputusan Keputusan Direksi PT. BPR Mitra Danagung Inderapura No. 002/SK-DIR/BPR-MD/2007, tanggal 17 September 2007 tentang Batas Kewenangan Pemberian Kredit.

3. Foto Copy Surat Direksi PT. BPR Mitra Danagung No. 0013/DIR/BPR-MD/IN-IV/2009, tanggal 27 April 2009 tentang Penempatan Karyawan.

4. Foto Copy Surat Keputusan Direksi tentang Perubahan Struktur Organisasi Karyawan PT. BPR Mitra Danagung tanggal 27 April 2009.

5. Dokumen-dokumen pengajuan kredit nasabah (para saksi) yang dipergunakan oleh pegawai bank/tersangka untuk pengajuan kredit fiktif sebanyak 23 (dua puluh tiga berkas), sebagai berikut:
a. Berkas Kredit Nasabah atas nama Murniati.
b. Berkas Kredit Nasabah atas nama Syamsurijal.
c. Berkas Kredit Nasabah atas nama Busli.
d. Berkas Kredit Nasabah atas nama Lizar.
e. Berkas Kredit Nasabah atas nama Zulandri.
f. Berkas Kredit Nasabah atas nama Dedeng Putra.
g. Berkas Kredit Nasabah atas nama Sika Rahmi. 
h. Berkas Kredit Nasabah atas nama Nasrizal.

i. Berkas Kredit Nasabah atas nama Yelpa Nora

j. Berkas Kredit Nasabah atas nama Sarniati.

k. Berkas Kredit Nasabah atas nama Yusmar Linda.

1. Berkas Kredit Nasabah atas nama Sustra Rida.

m. Berkas Kredit Nasabah atas nama Idel Miliharni.

n. Berkas Kredit Nasabah atas nama Yulia Erni.

o. Berkas Kredit Nasabah atas nama Yon Hendri.

p. Berkas Kredit Nasabah atas nama Ermansyah.

q. Berkas Kredit Nasabah atas nama Si El.

r. Berkas Kredit Nasabah atas nama Etmawati.

s. Berkas Kredit Nasabah atas nama Seprisma Yanto.

t. Berkas Kredit Nasabah atas nama Muso Laini.

u. Berkas Kredit Nasabah atas nama Eni Yarni.

v. Berkas Kredit Nasabah atas nama Sarifatul Jannah.

w. Berkas Kredit Nasabah atas nama Bustamuddin.

6. Foto Copi kwitansi pencairan dan Jurnal Harian Kredit Nasabah PT. BPR Mitra Danagung yang diduga fiktif.

7. Anggunan sertifikat dan alas hak lainnya yang diduga fiktif.

8. Dokumen pencairan platform kredit yang ditandatangani oleh pegawai bank itu sendiri.

9. SOP perkreditan yang berlaku di BPR Mitra Danagung

10. Buku Register Permohonan Kredit Tahun 2012 s/d 2013.

11. Neraca Harian nasabah PT. BPR Mitra Danagung yang diduga fiktif sebanyak 18 examplar.

12. Print Out rekening Koran pokok Debitur PT. BPR Mitra Danagung yang diduga fiktif sebanyak 22 (dua puluh dua) lembar.

13. SK Umum PT. BPR Mitra Danagung Tahun 2010 sebanyak 1 (satu) bundle.

14. Surat Keputusan Direksi PT. BPR Mitra Danagung Tahun 2011 sebanyak 1 (satu) bundle.

15. Foto copi akta pendirian perusahaan PT. BPR Mitra Danagung Inderapura yang dilegalisir oleh Lembaga Penjamin Simpanan sebanyak 1 (satu) bundle.

16. Foto Copy Salinan Keputusan Gubernur Bank Indonesia No: 15 / 94 / KEP.GBI / 2013 tentang Pencabutan Izin Usaha PT. BPR Mitra Danagung.

Berdasarkan bukti-bukti yang diperoleh oleh penyidik dari pegawai Bank BPR Mitra Danagung, penyidik kemudian bekerjasama dengan keterangan ahli Otoritas Jasa Keuangan (OJK) untuk menentukan apakah terdapat SOP perbankan yang dilanggar. Perlunya meminta OJK untuk memberikan keterangan ahli karena sebagaimana telah disinggung diawal bahwa tindak pidana kredit fiktif adalah tindak pidana khusus yang diatur diluar KUHP sehingga perlu pendekatan khususnya pula, terutama berkaitan dengan substansi tindak pidana yang dilakukan. Dari hasil keterangan ahli yang diberikan oleh OJK, penyidik memperoleh hasil bahwa tindakan 
yang dilakukan oleh pegawai Bank BPR Mitra Danagung adalah tindak pidana perbankan dalam bentuk kredit fiktif.

Setelah adanya bukti-bukti surat dan dokumen yang didapat oleh penyidik selama melakukan penyidikan dugaan tindak pidana kredit fiktif pada Bank BPR Mitra Danagung, ditambah dengan keterangan saksi serta keterangan ahli dari OJK, penyidik melakukan gelar perkara untuk menentukan siapa tersangka yang melakukan tindak pidana tersebut untuk kemudian dilakukan penangkapan dan penahanan yang dilengkapi dengan Surat Perintah Penangkapan dan Surat Perintah Penahanan.

Dari hasil pemeriksaan terhadap keterangan tersangka penyidik mendapati bahwa tindak pidana tersebut dilakukan dengan cara mempergunakan permohonan kredit nasabah yang telah lunas dan atau yang tidak disetujui oleh bank dengan anggunan yang fiktif dan setelah dana kredit cair dipergunakan oleh pelaku untuk kepentingan pribadinya, yang mana merupakan karyawan bank BPR Mitra Danagung itu sendiri.

Dihubungkan dengan ketentuan peraturan perundang-undangan yang mengatur tentang kredit fiktif, maka tersangka dapat tersangka diduga telah melanggar ketentuan Pasal 49 UndangUndang No. 10 Tahun 1998 tentang Perubahan Atas Undang-Undang No. 7 Tahun 1992 tentang Perbankan. Di dalam ayat (1) disebutkan bahwa: Anggota Dewan Komisaris, Direksi atau pegawai bank yang dengan sengaja:

a. Membuat atau menyebabkan adanya pencatatan palsu dalam pembukuan atau dalam proses laporan, maupun dalam dokumen atau laporan kegiatan usaha, laporan transaksi atau rekening suatu bank;

b. Menghilangkan atau tidak memasukkan atau menyebabkan tidak dilakukannya pencatatan dalam pembukuan atau dalam laporan, maupun dalam dokumen atau laporan kegiatan usaha, laporan transaksi atau rekening suatu bank;

c. Mengubah, mengaburkan, menyembunyikan, menghapus, atau menghilangkan adanya suatu pencatatan dalam pembukuan atau dalam laporan, maupun dalam dokumen atau laporan kegiatan usaha, laporan transaksi atau rekening suatu bank, atau dengan sengaja mengubah, mengaburkan, menghilangkan, menyembunyikan atau merusak catatan pembukuan tersebut, diancam dengan pidana penjara sekurang-kurangnya 5 (lima) tahun dan paling lama 15 (lima belas) tahun serta denda sekurang-kurangnya Rp. 10.000.000.000,- (sepuluh miliar rupiah) dan paling banyak Rp. 200.000.000.000,- (dua ratus miliar rupiah).

Sedangkan pada ayat (2) menyebutkan: Anggota Dewan Komisaris, Direksi, atau pegawai bank yang dengan sengaja:

a. Meminta atau menerima, mengizinkan atau menyetujui untuk menerim suatu imbalan, komisi, uang tambahan, pelayanan, uang atau barang berharga, untuk keuntungan pribadinya atau untuk keuntungan keluarganya, dalam rangka mendapatkan atau berusaha mendapatkan oralang lain dalam memperoleh uang muka, bank garansi, atau fasilitas kredit dari bank, atau dalam rangka pembelian atau pendiskontoan oleh bank atau surat-surat wesel, surat promes, cek, dan kertas dagang atau bukti kewajiban 
lainnya, ataupun dalam rangka memberikan persetujuan bagi orang lain untuk melaksanakan penarikan dana yang melebihi batas kreditnya pada bank;

b. Tidak melaksanakan langkah-langkah yang diperlukan untuk memastikan ketaatan bank terhadap ketentuan dalam undang-undang ini dan ketentuan peraturan perundangundangan lainnya yang berlaku bagi bank, diancam dengan pidana penjara sekurangkurangnya 3 (tiga) tahun dan paling lama 8 (delapan) tahun serta denda sekurrangkurangnya Rp. 5.000.000.000,- (lima miliar rupiah) dan paling banyak Rp. 100.000.000.000,- (seratus miliar rupiah)

Berdasarkan hasil penyidikan yang telah dilakukan oleh Penyidik Satreskrim Polresta Pesisir Selatan, terdapat petunjuk tentang adanya tindak pidana perbankan yang dilakukan oleh Risman Edrival selaku Direktur PT. BPR. Mitra Danagung dengan telah memenuhi unsur rumusan Pasal 49 ayat (1) huruf a Undang-Undang No. 10 Tahun 1998 tentang Perubahan Atas Undang-Undang No. 7 Tahun 1992 tentang Perbankan, maka dirinya telah dapat ditetapkan sebagai Tersangka.

Berdasarkan hasil pemeriksaan saksi-saksi dan para tersangka serta barang bukti yang ditemukan, tersangka melakukan pinjaman kredit dengan memakai identitas orang lain, padahal diketahui oleh para Tersangka bahwa perbuatan tersebut tidak dibenarkan dan tidak sesuai dengan Standar Operasional Prosedur (SOP) PT. BPR Mitra Danagung Inderapura.

Hasil penyidikan menunjukkan telah terjadinya peristiwa pidana berupa tindak pidana perbankan dalam bentuk pemberian pinjaman yang berupa fiktif atau direkayasa yang terjadi semenjak bulan Jauari 2011 sampai dengan bulan Desember 2012 oleh para Tersangka dengan memakai berkas nasabah atau nama orang lain.

Para Tersangka juga melibatkan beberapa Karyawan PT. BPR Mitra Danagung dalam melakukan perbuatan pidana tersebut. Tersangka meminta Accounting Officer, Administrasi Kredit, Pimpinan Cabang dan Direktur untuk menandatangni berkas kredit nasabah yang dipakai oleh tersangka sehingga kreditnya dapat dicairkan dan diambil oleh para tersangka seolah-olah kredit nasabah tersebut sudah lengkap dan telah disetujui oleh Pimpinan dan Direktur PT. BPR Mitra Danagung.

Dengan telah ditangkap dan ditahannya tersangka, maka tahapan selanjutnya yang dilakukan oleh penyidik adalah melakukan pemberkasan yang berisi resume sebagai ikhtisar dan kesimpulan dari hasil penyidikan tindak pidana kredit fiktif tersebut. Setelah pemberkasan selesai dilakukan maka penyidik menyerahkah berkas perkara ke Penuntut Umum. Pada saat berkas diserahkan kepada Penuntut Umum, Penuntut Umum menyatakan bahwa berkas telah lengkap sehingga barang bukti dan tersangka pun diserahkan oleh penyidik kepada Penuntut Umum.

Penyerahan barang bukti dan tersangka kepada Penuntut Umum merupakan tahap akhir dalam proses penyidikan tindak pidana.

Dalam sistem peradilan pidana seluruh kegiatan di dalam proses penyidikan pada dasarnya merupakan suatu hal yang bersifat berkesinambungan dan saling berkaitan antara satu proses dengan proses yang lain. 
Proses untuk menentukan suatu berkas perkara guna menentukan lengkap tidaknya berkas perkara tersebut untuk dilimpahkan di persidangan dalam rangkaian proses peradilan pidana terletak pada tahap Prapenuntutan yang menggambarkan adanya keterkaitan antara Penyidik dengan Penuntut Umum. Apabila terdapat kekurangan di dalam berkas perkara, yang nantinya akan menyulitkan Kejaksaan dalam melakukan penuntutan, maka berkas perkara dapat dikembelikan kepada Penyidik untuk disempurnakan dengan disertai petunjuk yang dianggap perlu.

Pada prinsipnya, ketentuan tentang Penyidikan dan Penuntutan dalam KUHAP menunjukkan hubungan yang erat antara penyidikan dengan penuntutan. Secara ringkas dapat dikatakan bahwa penyidikan merupakan kegiatan untuk mengumpulkan alat bukti mengenai adanya satu tindak pidana beserta pelaku tindak pidana tersebut, sementara penuntutan merupakan kegiatan yang ditujukan untuk mempertanggungjawabkan hasil dari kegiatan penyidikan di forum pengadilan. Oleh karena itu, pelaksanaan dari integrated criminal justice system sebetulnya adalah untuk melaksanakan penegakan hukum yang terpadu dan berkesinambungan untuk mendapatkan out put yang maksimal. Dalam hal ini, penyidikan haruslah diarahkan kepada pembuktian di persidangan, sehingga tersangka (pelaku tindak pidana) dapat dituntut dan diadili di persidangan. Penyidikan yang berakhir dengan putusan ataupun lepas dari segala tuntutan dari Pengadilan terhadap pelaku tindak pidana akan merugikan masyarakat dan lembaga penegak hukum itu sendiri.

\section{Kendala-Kendala yang dihadapi Penyidik Satreskrim Polres Pesisir Selatan pada Penyidikan Tindak Pidana Perbankan dalam Bentuk Kredit Fiktif pada Bank BPR Mitra Danagung}

Pengungkapan tindak pidana bukanlah hal yang mudah untuk dilaksanakan oleh aparat kepolisian, apalagi jika tindak pidana tersebut dilakukan secara sistematis. Pengungkapan suatu kejahatan kadang-kadang harus menempuh jalan yang sulit agar bukti-bukti dapat dikumpulkan guna menemukan dan menangkap pelaku tindak pidana tersebut. Karenanya aparat penegak hukum harus dapat dengan piawai mengungkap kejahatan, tanpa harus melakukan kekerasan atau penyiksaan.

Pihak kepolisian dalam melaksanakan penyelidikan tindak pidana jangan hanya mengejar pengakuan tersangka, tetapi dapat pula ditempuh dengan jalan mencari barang bukti dan alat bukti yang dapat mendukung kebenaran atas suatu perbuatan yang disangkakan kepadanya.

Dalam penegakan hukum, kendala-kendala sebagaiman yang ditemui oleh Penyidik Satreskrim Polres Pesisir Selatan, dapat ditinjau dari segi faktor hukumnya maupun aparat serta sarana penegakan hukum itu sendiri.

Apabila ditinjau dari segi hukumnya, kita akan menemukan tumpang tindihnya kewenangan penyidikan tindak pidana perbankan, khususnya tindak pidana kredit fiktif. Peraturan perundang-undangan sama-sama memberikan kewenangan kepada 3 (tiga) instansi sekaligus, yakni: Kepolisian, OJK, dan KPK. Tumpang tindih ini lah yang terkadang menjadi 
kendala bagi kepolisian karena ketiga instansi hukum ini memiliki kewenangan dalam penyidikan tindak pidana di bidang perbankan.

Dalam pandangan penulis, perlu ada penegasan/penjelasan, mengingat pengakan hukum pidana sangat terkait dengan hak asasi manusia, jadi jika suatu lembaga mempunyai kewenangan dalam hal penegakan hukumnya harus diatur secara limitative, hal ini disebabkan bahwa dalam hukum pidana menganut asas legalitas.

Kewenangan penyidikan yang diberikan selain kepada Kepolisian apabila terus dipertahankan bukankah hal terseut akan mengacaukan pelaksanaan penyidikan-penuntutan menurut aturan KUHAP.

Marjono Reksodiputro menjelaskan bahwa sistem peradilan pidana merupakan sistem pengendalian kejahatan yang dilakukan subsistem-subsitem tersebut dengan tujuan:

1. Mencegah masyarakat menjadi korban kejahatan.

2. Menyelesaikan kasus kejahatan yang terjadi sehingga masyarakat puas bahwa keadilan telah ditegakkan dan yang bersalah telah dipidana.

3. Mengusahakan agar mereka yang pernah melakukan kejahatan tidak mengulangi lagi kejahatannya. $^{19}$

Lebih lajut menurut Muladi Sistem peradilan didalamnya terkandung gerak sistemik dari subsistem-subsistem pendukung (Kepolisian, Kejaksaan, Pengadilan dan Lembaga Pemasyarakatan) yang secara keseluruhan dan merupakan satu kesatuan (totalitas) berusaha mentrasformasikan masukan (input) menjadi keluaran (output) yang menjadi tujuan sistem peradilan pidana yang berupaya resosialisasi pelaku tindak pidana (jangka pendek), pencegahan kejahatan (jangka menengah) dan kesejahteraan sosial (jangka panjang). Untuk itu perlu adanya sinkronisasi pelaksanaan penegakan hukum dikalangan subsistem-subsistem. Jika keterpaduan subsistem-subsistem dalam sistem peradilan pidana tidak terwujud, masyarakat dapat beranggapan bahwa sistem peradilan pidana menyebabkan timbulnya kejahatan. ${ }^{20}$

Didasari pada uraian tersebut diatas, maka jelaslah bahwa soal kewenangan masingmasing sub-sistem dalam sistem peradilan pidana sangat menentukan sekali dalam rangka penegakan hukum, terutama pada tindak pidana perbankan yang dikenal sebagai white collar crime.

Selanjutnya kendala-kendala yang terjadi pada penyidikan tindak pidana kredit fiktif pada Bank BPR Mitra Danagung juga berasal dari faktor struktur/penegak hukum itu sendiri.

Keterbatasan Sumber Daya Manusia/personel aparat kepolisian merupakan hal yang tidak asing lagi. Selain dari pada itu, tingkat pengetahuan SDM Polri yang benar-benar kompeten dalam penyidikan tindak pidana kredit fiktif.

Jenjang pendidikan memainkan peranan yang sangat vital dalam membentuk kualitas seseorang. Idealnya seseorang yang berkualifikasi pendidikan yang baik akan tergambar melalui prilaku orang tersebut. Dalam konteks ini, seorang polisi dituntut untuk dapat memahami prosedur dan tata cara penyelidikan secara baik sehingga dapat proses penyelidikan tindak

${ }^{19}$ Anthon F. Susanto, Wajah Peradilan Kita, Refika Aditama, Bandung, 2004, hlm. 73-74

${ }^{20}$ Muladi, Kapita Selekta Sistem Peradilan Pidana, Badan Peneliti Universitas Diponegoro, Semarang, 1995, hlm. vii 
pidana dapat dilakukan dengan sebaik mungkin untuk menemukan kejahatan yang terus berkembang di masyarakat dan mengetahui perangkat hukum yang hendak diancamkan kepada penjahatnya (accussed). Untuk melakukannya maka kualifikasi pendidikan sangat dibutuhkan.

Kondisi ini kemudian diperparah dengan kurangnya penguasaan penyidik dalam penggunaan teknologi informasi. Faktor ini membutuhkan ilmu yang tinggi untuk dipelajari dengan cepat karena kemajuan teknologi semakin berkemang memudahkan bagi pelaku tindak pidana perbankan, khususnya kredit fiktif menjadi mudah. Teknologi yang semakin berkembang mempermudah pelaku kredit fiktif untuk mengalihkan hasil kejahatannya dengan cepat. Hal ini tentunya akan mempersulit pengembalian asset/keuangan negara yang telah dirugikan.

Hal ini tentunya berlawanan dengan harapan, bahwa kepolisian sebagai alat penegak hukum, yang harusnya mempunyai kemampuan mumpuni dalam penegakan hukum. Sebagai penegak hukum sudah seharusnya seorang penyidik memiliki jenjang pendidikan dan pengetahuan serta keterampilan yang baik dalam rangka meningkatkan kualitas SDM penyidik Polri, yang pada akhirnya akan berdampak pada penegakan hukum itu sendiri.

Pada lain sisi, kapabilitas aparat penegak hukum dapat dikatakan masih rendah, sementara tindak pidana di bidang perbankan merupakan kejahatan yang berdimensi kejahatan yang terorganisir dengan baik dengan karaktekristiknya tersendiri. Dalam penyidikan kejahatan yang berhubungan dengan lalu lintas keuangan, aparat penegak hukum (terutama penyidik) selain memhami bidang hukum juga harus memiliki latar belakang bidang ilmu lainnya, seperti ilmu ekonomi.

Selanjutnya berkaitan dengan saran dan prasaran yang mendukung pelaksanaan penyidikan tindak pidana perbankan dalam bentuk kredit fiktif. Mengingat tindak pidana kredit fiktif merupakan salah satu kejahatan yang terorganisir, maka dalam penangannya juga akan berbeda dengan penganan tindak pidana biasa. Perkembangan teknologi yang semakin pesat seharusnya diiringi dengan infrastruktur yang memadai. Karenanya adalah suatu keharusan agar penanganan tindak pidana perbankan tidak menemui kendala dan dapat lebih optimal.

\section{KESIMPULAN}

Berdasarkan hasil pembahasan yang telah dilakukan, maka dapat penulis simpulkan bahwa Penyidikan tindak pidana perbankan dalam bentuk kredit fiktif pada Bank PBR Mitra Danagung dilakukan berdasarkan ketentuan Undang-Undang No. 7 Tahun 1992 tentang Perbankan sebagaimana telah diubah dengan Undang-Undang No. 10 Tahun 1998 tentang Perubahan Atas Undang-Undang No. 7 Tahun 1992 tentang Perbankan. Setelah menerima laporan, tim penyidik melakukan penyidikan dan pengkajian terhadap laporan tersebut untuk menyusun rencana kegiatan penyidikan. Kemudian dilanjutkan dengan melakukan pemeriksaan terhadap saksi-saksi dan pengumpulan bukti serta keterangan ahli. Berdasarkan keterangan saksi, bukti-bukti dan keterangan ahli kemudian dilakukanlah gelar perkara untuk menentukan siapa tersangkanya untuk selanjutnya dilakukan penangkapan dan penahanan. Setelah seluruh pemberkasan selesai, kemudian penyidik menyerahkan berkas perkara kepada Penuntut Umum disertai dengan penyerahan saksi dan alat bukti, Adapun kendala yang dihadapi oleh penyidik 
Satreskrim Polres Pesisir Selatan pada penyidikan tindak pidana perbankan dalam bentuk kredit fiktif pada Bank BPR Mitra Danagung adalah: tumpang tindih kewenanangan penyidikan tindak pidana perbankan yang diatur oleh Undang-Undang yang memberikan kewenangan kepada Kepolisian, Kejaksaan, dan Penyidik OJK, keterbatasan SDM Penyidik, tingkat pendidikan dan rendahnya pengetahuan penyidik tentang kemajuan teknologi informasi, serta sarana dan prasaran pendukung dalam melakukan penyidikan.

\section{DAFTAR PUSTAKA}

Anthon F. Susanto, Wajah Peradilan Kita, Refika Aditama, Bandung, 2004

Barda Nawawi Arief, Kapita Selekta Hukum Pidana Tentang System Peradilan Pidana Terpadu, BP Undip, Semarang, 2007

Barda Nawawi Arief, Reformasi Sistem Peradilan (Sistem Penegakan Hukum di Indonesia), Cet. II BP Undip, Semarang, 2011

Candra M. Hamzah, Penejelasan Hukum Tentang Bukti Permulaan Yang Cukup, Pusat Studi Hukum dan Kebijakan Indonesia (PSHK), Jakarta, 2014

Edi Setiadi, Kristian, Sistem Peradilan Pidana Terpadu dan Sistem Penegakan Hukum di Indonesia, Edisi Pertama, Prenadamedia Group, Jakarta, 2017

I Ketut Sudira, Mediasi Penar Perkara Penelantaran Rumah Tangga, UII Press, Yogyakarta, 2016

Marfein Halim, Mengurai Benang Kusut, Bank Indonesia, Jakarta, 2002

Muladi, Kapita Selekta Sistem Peradilan Pidana, Badan Peneliti Universitas Diponegoro, Semarang, 1995

Muladi, Kapita Selekta Sistem Peradilan Pidana, Undip, Semarang, 1995

Putusan Nomor 71/Pid.Sus/2018/PN Pnn

Sudikno Mertokusumo, Mengenal Hukum (Suatu Pengantar), Edisi Ketiga, Liberty, Yogyakarta, 1991

Teguh Pudjo Mulyono, Manajemen Perkreditan Bagi Bank Komersil, BPFE, Yogyakarta, 2006

Undang-Undang Nomor 1 Tahun 1946 tentang Peraturan Hukum Pidana (KUHP);

Undang-Undang Nomor 8 Tahun 1981 tentang Hukum Acara Pidana (KUHAP);

Undang-Undang Nomor 7 Tahun 1992 tentang Perbankan;

Undang-Undang Nomor 10 Tahun 1998 tentang Perubahan Atas Undang-Undang Nomor 7 Tahun 1992 tentang Perbankan;

Undang-Undang Nomor 2 Tahun 2002 tentang Kepolisian Negara Republik Indonesia;

Undang-Undang Nomor 21 Tahun 2011 tentang Otoritas Jasa Keuangan;

Peraturan Pemerintah Nomor 58 Tahun 2010 tentang Perubahan Atas Peraturan Pemerintah Nomor 27 Tahun 1983 tentang Pelaksanaan Kitab Undang-Undang Hukum Acara Pidana;

Peraturan Otoritas Jasa Keuangan No. 22/POJK.01/2015 tentang Penyidikan Tindak Pidana di Sektor Jasa Keuangan;

Peraturan Kepala Kepolisian No. 6 Tahun 2019 tentang Penyidikan Tindak Pidana

Peraturan Kepolisian Negara Republik Indonesia Nomor 2 Tahun 2021 tentang Susunan Organisasi Dan Tata Kerja Pada Tingkat Kepolisian Resor Dan Kepolisian Sektor

http://www.tribunnews.com/regional/2017/05/19/komplotan-kredit-fiktif-ini-berhasil-bobo-11unit-bri-pakai-suami-istri-palsu?page $=1$, 
https://news.detik.com/berita-jawa-barat/d-4188680/kredit-fiktif-rp-183-t-pejabat-bank-didakwa20-tahun-bui

https://www.viva.co.id/berita/nasional/1110407-karyawan-korupsi-kredit-fiktif-rp4-2-miliardihukum-bui-lima-tahun 